\title{
A Researchon Job Enrichment and Redesigning of Work in Indian Manufacturing Companies
}

\author{
J.Rengamani, Fabian Andrew James, R.Srinivasan, S.Poongavanam, R.Vettriselvan
}

\begin{abstract}
Job Enrichment is the most important aspect of any organisation especially with regard to manufacturing companies in India. To add up with that the redesigning of work done by the employees in the manufacturing companies will make the employees to work in an efficient manner. The employees will show higher productivity when they are motivated by the organisations. There are different ways of motivating employees in the organisations which include financial motivation and nonfinancial motivation. The belongingness of employees can be increased only when the employees are properly motivated. The self motivated employees will display higher productivity levels. The increase in productivity will lead to the increase in the performance of achieving their goals and objectives in the shortest period of time. The article tries to identify the importance of job enrichment and redesigning of work among employees who are working in the manufacturing companies in India.
\end{abstract}

Keywords - Job Enrichment, Job redesign, Motivation, Job Satisfaction, Productivity.

\section{INTRODUCTION}

Job enrichment is the most powerful tool through which the employees of the organisation can be motivated by allocating additional work in order to elicit the hidden talents of the employees and make them work more efficiently and effectively. The employees of the organisation would naturally possess the ability to work harder and succeed in their endeavour by achieving the target given to them. This ability can be kindled more by making elevating them to do the work at a higher level. The employees must be allocated with the challenging work otherwise they tend to wear off by doing the routine work. Job enrichment will make the employees to take up additional responsibility so as to prove their abilities in achieving things in the organisation. When the employees are made to work independently then they will intend to take the additional responsibility and will try to achieve the goal by using their abilities to the fullest extent possible. The outcome of job enrichment will be higher productivity which will be really beneficial to the organisation.

Job enrichment will make the employees to acquire new skill sets by undertaking newresponsibilities. The new assignment will make the employees to put in more efforts and it will make the employees to think in right direction towards achieving the set tasks. The employees will become

Revised Manuscript Received on April 12, 2019.

Dr.J.Rengamani,AMET Business School, AMET University, Chennai.T.N, India.

Dr.Fabian Andrew James, AMET Business School, AMET University, Chennai.T.N, India. Chennai.T.N, India.

Dr.S.Poongavanam,AMET Business School, AMET University, Chennai.T.N, India.

Dr.R.Vettriselvan, AMET Business School, AMET University, Chennai.T.N, India.
Dr.R.Srinivasan, AMET Business School, AMET University,

more aware of the additional role and responsibilities and there are possibilities of even becoming experts in the assigned areas. Job enrichment will enable the employees to do new things at their interest and hence doing routine work can be minimized. Job enrichment will provide better working environment to the employees in the organisation and this will have a direct impact on the increase in productivity.

On the other hand, Job enrichment will make the employees to work harder and hence their workload will increase drastically. The additional pressure undertaken by the employees will make them feel exhausted in the new work environment and this will create a sort of aversion in doing new things. By assuming new roles and responsibilities, the employees must be ready to exhibit their skills and this aspect requires more preparation on the part of the employees. When the employees are not ready to adapt to the new role then the productivity of the employees will be affected. In every organisation, there are employees who perform exceedingly well and there are employees who will not be ready to accept the new challenges. When the performing employees meet the underperforming employees in the new concept of job enrichment, both will clash with each other. The major problem of job enrichment is the performance of employees in the new environment and the non-performers will face a drastic problem in the organisation. Moreover, the amount of work done by the employees will increase to a greater extent and this issue will make the employees to shy away from accepting new roles and responsibilities.

\section{OBJECTIVES OF THE STUDY}

- To study the impact of job enrichment among the employees of manufacturing companies in India

- To study the importance of the redesigning of work to make the employees work productively

\section{HYPOTHESIS}

H01: There is no significant relationship between motivation and job satisfaction

H02: There is no significant relationship between working climate and working condition

\section{METHODOLOGY OF RESEARCH}

The study used questionnaire to collect data from the employees of manufacturing organisations in India. The

sampling method used in this

Published By:

Blue Eyes Intelligence Engineering 
study is quota sampling by which the questionnaire was administered to various employees. The questionnaire elicited information based on job enrichment and the redesigning of work and the ways of motivating factors.

\section{DATA ANALYSIS AND RESULTS INTERPRETATIONS}

Table-1: Nature of Motivation

\begin{tabular}{|l|c|c|}
\hline Level of satisfaction & Nos. & Percentage \\
\hline Highly satisfied & 30 & $30 \%$ \\
\hline Satisfied & 40 & $40 \%$ \\
\hline Somewhat satisfied & 25 & $25 \%$ \\
\hline Dissatisfied & 5 & $5 \%$ \\
\hline & 100 & $100 \%$ \\
\hline
\end{tabular}

Inference: The above table shows $40 \%$ of population are satisfied with the nature of motivation, $30 \%$ are highly satisfied, $25 \%$ are somewhat satisfied and $5 \%$ are dissatisfied. It shows that majority of respondents are satisfied with nature of the motivation provided in the company.

Table-2: Motivation by individual employees

\begin{tabular}{|l|c|c|}
\hline Level of satisfaction & Nos. & Percentage \\
\hline Highly satisfied & 30 & $30 \%$ \\
\hline Satisfied & 50 & $50 \%$ \\
\hline Somewhat satisfied & 10 & $10 \%$ \\
\hline Dissatisfied & 10 & $10 \%$ \\
\hline & 100 & $100 \%$ \\
\hline
\end{tabular}

Inference: The above table shows Satisfied is half of the total population while highly satisfied and somewhat satisfied is placing the second and third place respectively.

Table-3: Work climate and motivation

\begin{tabular}{|l|c|c|}
\hline Level of satisfaction & Nos. & Percentage \\
\hline Highly satisfied & 35 & $35 \%$ \\
\hline Satisfied & 45 & $45 \%$ \\
\hline Somewhat satisfied & 15 & $15 \%$ \\
\hline Dissatisfied & 5 & $5 \%$ \\
\hline & 100 & $100 \%$ \\
\hline
\end{tabular}

Inference: The above table shows $45 \%$ of the total population aresatisfied with the work climate and motivation, $35 \%$ are highly satisfied, $15 \%$ are somewhat satisfied and $5 \%$ are dissatisfied.

Table-4: Flow of information

\begin{tabular}{|l|c|c|}
\hline Level of satisfaction & Nos. & Percentage \\
\hline Highly satisfied & 30 & $30 \%$ \\
\hline Satisfied & 50 & $50 \%$ \\
\hline Somewhat satisfied & 12 & $12 \%$ \\
\hline Dissatisfied & 8 & $8 \%$ \\
\hline & 100 & $100 \%$ \\
\hline
\end{tabular}

Inference: The above table shows the satisfied people percentage is half of the total numbers, highly satisfied people level is $30 \%$ of total, somewhat satisfied and dissatisfied level is placing third and fourth.

Table-5: Relationship with other people

\begin{tabular}{|l|c|c|}
\hline Level of satisfaction & Nos. & Percentage \\
\hline Highly satisfied & 50 & $50 \%$ \\
\hline Satisfied & 40 & $40 \%$ \\
\hline Somewhat satisfied & 10 & $10 \%$ \\
\hline Dissatisfied & 0 & $0 \%$ \\
\hline & 100 & $100 \%$ \\
\hline
\end{tabular}

Inference: The above table shows $50 \%$ is of the total population is highly satisfied, $40 \%$ is satisfied, $10 \%$ is somewhat satisfied and Dissatisfied is nil.

Table-6: Flexibility and freedom of work

\begin{tabular}{|l|c|c|}
\hline Level of satisfaction & Nos. & Percentage \\
\hline Highly satisfied & 30 & $30 \%$ \\
\hline Satisfied & 40 & $40 \%$ \\
\hline Somewhat satisfied & 30 & $30 \%$ \\
\hline Dissatisfied & 0 & $0 \%$ \\
\hline & 100 & $100 \%$ \\
\hline
\end{tabular}

Inference: The above table shows $40 \%$ of population is of satisfied, $30 \%$ is highly satisfied, another $30 \%$ is somewhat satisfied and dissatisfied is nil.

Table-7: Level of supervision in motivation

\begin{tabular}{|l|c|c|}
\hline Level of satisfaction & Nos. & Percentage \\
\hline Highly satisfied & 45 & $45 \%$ \\
\hline Satisfied & 40 & $40 \%$ \\
\hline Somewhat satisfied & 10 & $10 \%$ \\
\hline Dissatisfied & 5 & $5 \%$ \\
\hline & 100 & $100 \%$ \\
\hline
\end{tabular}

Inference: The above table shows $45 \%$ of total population is of highly satisfied, $40 \%$ is satisfied, $10 \%$ is somewhat satisfied and $5 \%$ is dissatisfied.

Table-8: Motivation creates personality

\begin{tabular}{|l|c|c|}
\hline Level of satisfaction & Nos. & Percentage \\
\hline Highly satisfied & 30 & $30 \%$ \\
\hline Satisfied & 50 & $50 \%$ \\
\hline Somewhat satisfied & 20 & $20 \%$ \\
\hline Dissatisfied & 0 & $0 \%$ \\
\hline & 100 & $100 \%$ \\
\hline
\end{tabular}

Inference: The above table shows $50 \%$ of total population is of satisfied, $30 \%$ is highly satisfied, $20 \%$ is somewhat satisfied and no one is dissatisfied.

\section{Relationship between Motivation and job satisfaction}

Hypothesis: there is no significant relationship between motivation and job satisfaction

Calculated value 2.25

Table value is 7.11

Df $(3-1),(3-1)=4$

Since the calculated value is less than the table value the

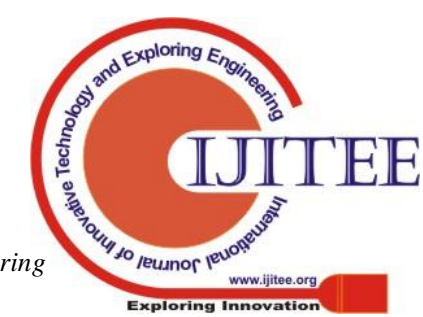


hypothesis is accepted and there is significant relationship between motivation and job satisfaction.

Table-9: Interaction between other employees

\begin{tabular}{|l|c|c|}
\hline Level of satisfaction & Nos. & Percentage \\
\hline Highly satisfied & 36 & $36 \%$ \\
\hline Satisfied & 45 & $45 \%$ \\
\hline Somewhat satisfied & 12 & $12 \%$ \\
\hline Dissatisfied & 7 & $7 \%$ \\
\hline & 100 & $100 \%$ \\
\hline
\end{tabular}

Inference: The above table shows $45 \%$ of population is of Satisfied, $36 \%$ is highly satisfied, $12 \%$ is somewhat satisfied and $7 \%$ is dissatisfied.

Table-10: Changes in organizational development

\begin{tabular}{|l|c|c|}
\hline Level of satisfaction & Nos. & Percentage \\
\hline Highly satisfied & 30 & $30 \%$ \\
\hline Satisfied & 40 & $40 \%$ \\
\hline Somewhat satisfied & 20 & $20 \%$ \\
\hline Dissatisfied & 10 & $10 \%$ \\
\hline & 100 & $100 \%$ \\
\hline
\end{tabular}

Inference: The above table shows of $40 \%$ of total population is of satisfied, $30 \%$ is highly satisfied, $20 \%$ is somewhat satisfied and $10 \%$ is dissatisfied.

Table-11: Changes in work environment

\begin{tabular}{|l|c|c|}
\hline Level of satisfaction & Nos. & Percentage \\
\hline Highly satisfied & 50 & $50 \%$ \\
\hline Satisfied & 30 & $30 \%$ \\
\hline Somewhat satisfied & 10 & $10 \%$ \\
\hline Dissatisfied & 10 & $10 \%$ \\
\hline & 100 & $100 \%$ \\
\hline
\end{tabular}

Inference: The above table shows $50 \%$ of total population is highly satisfied, $30 \%$ is satisfied, somewhat satisfied and dissatisfied is more or less the same percentage.

Table-12: Identify within groups

\begin{tabular}{|l|c|c|}
\hline Level of satisfaction & Nos. & Percentage \\
\hline Highly satisfied & 50 & $50 \%$ \\
\hline Satisfied & 30 & $30 \%$ \\
\hline Somewhat satisfied & 10 & $10 \%$ \\
\hline Dissatisfied & 10 & $10 \%$ \\
\hline & 100 & $100 \%$ \\
\hline
\end{tabular}

Inference: The above table shows $50 \%$ of total population is highly satisfied, $30 \%$ is satisfied, somewhat satisfied and dissatisfied is more or less the same percentage.

Table-13: Participation in decision making

\begin{tabular}{|l|c|c|}
\hline Level of satisfaction & Nos. & Percentage \\
\hline Highly satisfied & 40 & $40 \%$ \\
\hline Satisfied & 50 & $50 \%$ \\
\hline Somewhat satisfied & 5 & $5 \%$ \\
\hline Dissatisfied & 5 & $5 \%$ \\
\hline & 100 & $100 \%$ \\
\hline
\end{tabular}

Inference: The above table shows $50 \%$ of total population is of satisfied, $40 \%$ is highly satisfied, somewhat satisfied and dissatisfied is very low percentage.

Table-14: Future achievement

\begin{tabular}{|l|c|c|}
\hline Level of satisfaction & Nos. & Percentage \\
\hline Highly satisfied & 40 & $40 \%$ \\
\hline Satisfied & 50 & $50 \%$ \\
\hline Somewhat satisfied & 10 & $10 \%$ \\
\hline Dissatisfied & 0 & $0 \%$ \\
\hline & 100 & $100 \%$ \\
\hline
\end{tabular}

Inference: The above table shows 50\%highly satisfied and satisfied is somewhat narrow and none has dissatisfied.

Chi-square test

Relationship Working climate and working condition

Hypothesis:No significant relationship between working climate and working condition

Dfis 4

Calculated value is 3.442

Table value is 1.064

Since the calculated value is greater than the table value hypothesis is rejected and there is significant relationship between working climate and working condition.

\section{CONCLUSION}

The redesigning of work through job enrichment is considered to be a brilliant idea of improving the job satisfaction, lesser productivity in the organisations and the idea of resigning the job will be drastically reduced. The job enrichment will motivate the employees to work in the best possible manner in the organisation to a greater extent. The skill set of the employees will also be improved making them to think in an independent manner for the benefit of the organisation. When the employees show greater productivity then their services will also be recognised by the organisation. The job enrichment will be doubly and mutually beneficial to both the organisation and the employees who are intended to work for the organisation. The commitment of the employees towards achieving the set goals and tasks will be on the higher side, making them to work harder and smarter. The job enrichment process is the dynamic process through which the job can be redesigned so as to suit the employees and this will make the employees to achieve the target at a quicker pace.

\section{REFERENCES}

1. Balachandran, "The application of Job enrichment in the organisations", Journal of Management Studies

2. S.P.Gupta, "Statistics", Sultan Chand and Sons

3. Selvaraj.A.M, "A study on the Human Resource Information System in Human Resource Planning", Journal of Advanced Research Studies 